\title{
Convergence of a Strengths Perspective and Youth Development: Toward Youth Promotion Practice
}

\author{
Jeong Woong Cheon
}

\begin{abstract}
In recent years, increased attention has been paid to the development and application of the strengths perspective and positive youth development. This paper develops youth promotion practice as a convergence of a strengths perspective and youth development principles. Historical and contemporary contexts of a problem-focused perspective in social work with adolescents are reviewed and a critique developed with emphasis on the evolution of strengths-focused practices. The importance and possibility of combining the strengths perspective and youth development toward youth promotion practice are addressed. Youth promotion is defined as a process of enhancing youth strengths and resources to promote positive outcomes and help young people be healthy adults. Complementary aspects of the two perspectives are expected to support and supplement the strengths and weaknesses of each perspective in synergistic ways. Several advantages of youth promotion practice are discussed as well as its implications for improved social work practices with adolescents.
\end{abstract}

Keywords: Strengths perspective; youth development; youth promotion; problemfocused; strengths-based practice.

\section{INTRODUCTION}

There has been increasing attention given to the positive aspects and strengths of adolescents over the past two decades in the human development, social work, and related fields (Amodeo \& Collins, 2007; Saleebey, 2005). More interest in the strengths perspective, positive psychology, quality of life, psychological wellness, and health promotion has been emphasized in social work and allied fields (Crowe, 2007; Maton, Schellenbach, Leadbeater, \& Solarz, 2004). In particular, resilience and youth development have gained prominence as ways to help adolescents become competent and responsible adults (Benard, 2004; Clary \& Rhodes, 2006).

However, the image of "youth as problems" is still dominant in public discourse, professional work, and social science (Males, 1996; Scales, 2001). Social work has essentially tied its tradition to problems, deficits, and diagnoses rather than strengths and resources. Social work theory and practice have been more interested in troubled youth and the services they require, and youth development is less emphasized than treatments and therapeutic interventions compared to other disciplines (Melpignano \& Collins, 2003; Morrison, Alcorn, \& Nelums, 1997). Although many agencies state that they practice using the strengths perspective and youth development principles, the field needs more efforts to incorporate these strengths-based practices for improved social work practices with young people.

Jeong Woong Cheon, Ph.D., is a research manager in the School of Social Welfare at the University of Kansas.

Copyright (C) 2008 Advances in Social Work Vol. 9 No. 2 (Fall 2008), 176-190 
This paper proposes youth promotion practice as a convergence of a strengths perspective and youth development principles. It reviews the historical and contemporary contexts of the problem-focused perspectives on adolescents, and then develops a critique with emphasis on a strengths perspective and youth development principles. The importance and possibility of the youth promotion practice are addressed. It concludes with discussion of the advantages of youth promotion practice and its implications for improved social work practice with adolescents.

\section{HISTORICAL CONTEXTS OF PRACTICE WITH YOUTH}

According to popular and professional thinking, young people are understood as either problems or victims rather than strengths or resources. Mass media often portray young people as violent, drug addicted, pregnant, dropouts, or homeless (Nichols \& Good, 2004). Youth of color and those youth from low-income backgrounds or residing in urban areas usually have been viewed more negatively than other youth from a deficit perspective (Delgado, 2002).

In order to understand the negative perspective toward young people, it is necessary to examine the historical evolution of youth issues, the conceptualization of the dominant discourse on adolescence and their relation to intervention by the social work professionals as responding to the problems of young people. Although youth issues can be found throughout history, the first time that youth became objects of heightened public concern can be traced as far back as the 1830s with the development of America's first urban slums (Trattner, 1999).

Social welfare agencies participated in the child-saving movement, "orphan trains" and the junior republic movement of the $19^{\text {th }}$ century urban youth crisis (Trattner, 1999). Several youth-serving organizations were created in the 1850s, along with religious and charitable groups, to meet the needs of young working people including the Young Men's Christian Association (YMCA) and the Young Women's Christian Association (YWCA). In 1889, Jane Addams established Hull House, the best known settlement house, with the intention of protecting and promoting the development of young people and well-being of their families (Addams, 1910). Youth services agencies and settlement houses utilized group work and emphasized character building. Settlement houses and youth service agencies were once extensively staffed with professionally trained social workers. However, today they staff relatively few of the neighborhood-based youth services (Morrison et al., 1997).

In the beginning of $20^{\text {th }}$ century, the concept of adolescence as a special time between childhood and adulthood had been developed. In 1904, Hall (1904) introduced the concept of adolescence as a time of "storm and stress" to explain the behaviors of youth. He wrote that "development is less gradual and more salutatory, suggestive of some ancient period of storm and stress" (p. xiii). Hall's "storm and stress" description of adolescence influenced adults' perception of adolescence as a stormy period of life and it was internalized by society as a way to describe the typical teenagers (Nichols \& Good, 2004). 
With the dominant view of adolescence as a stage of turmoil, youth have been viewed by social workers as problems to be solved or victims to be saved (Finn \& Checkoway, 1998). Social workers began to call for a more professional approach, and more attention was paid to the problems in people's lives; thus interest in community work was decreased (Day, 2000). Studies of pathology and individual differences were incorporated into the casework approach to social work practice.

By the late 1930s, the social work profession was shifting toward a psychoanalytic approach as the dominant theoretical structure for defining individuals' problems (Weick, Rapp, Sullivan, \& Kisthardt, 1989). For example, Freud (1946) argued that youth were inevitably fraught with parent-child conflict. According to de Anda (1995), psychoanalytic theorists see "the developmental processes of adolescence as a recapitulation of earlier infantile stages of development through the re-experiencing of either oedipal or pre-oedipal conflicts" (p.18). The psychoanalytic theory and its derivatives further facilitated pathology theories in their practice with youth (Day, 2000).

By the 1950s, the psychiatric approach and psychosocial approach seemed to exist together. Although psychosocial theories of adolescents emphasized the impact of the sociocultural context on individual development, the two approaches still focused on problems (McMillen, Morris, \& Sherraden, 2004). A problem-solving framework for social casework was also introduced and prevailed as one of social work's durable practice models. Moreover, the negative conceptualization of adolescence was further introduced during this period. For example, Erikson (1963) also viewed adolescence as a time of turmoil and stress characterized by the result of an "identity crisis." For Erikson, adolescence came to signify both key physiological changes and the development of a separate independent adult identity.

As the mental health field began to emerge in the profession, problem-focused and deficit-based perspectives and practices became more dominant among social workers (Finn, 2001). In the early 1980s, troubled youth were increasingly pushed into residential hospitals for treatment. Males (1996) asserts that the commitment of adolescents to psychiatric treatment was not increased by a rise in mental health problems of young people, but promoted more by hospital profiteering. Finn (2001) discusses the ways in which particular images of pathology are appropriated and deployed in the constructions of troubled youth. She contends that "young people are assessed and diagnosed in an ever-expanding taxonomy of risk, danger, and pathology" (p. 184).

\section{EVOLUTION OF A STRENGTHS PERSPECTIVE AND YOUTH DEVELOPMENT}

Although social work played an important role in dealing with the problems of young people, the problem-focused understanding of adolescence has been too dominant. The neglect of youth's “social agency" has been one of the consequences, and society may miss important opportunities to keep young people on a positive trajectory. Problemfocused perspectives are criticized as promoting a construction of adolescence itself as pathology (Delgado, 2000). 
A challenge to biological determinism has been posed along with the conceptualization of adolescence. Many studies have contradicted the understanding of adolescence as a universal life stage of "storm and stress." For instance, Mead (1928) argues through her study of adolescent girls in Samoa that youth do not experience a turbulent time. Rather, given the appropriate cultural context, teenage years could be ages of gradual, peaceful transition to adulthood. In the 1960s, Bandura (1964) reported that published research data showed that the view of "storm and stress" was unwarranted and rather argued that the mass media sensationalizes adolescent behavior. Arnett (1999) found that when asked about teens as a group, adults were more likely to characterize them in negative terms.

Problem-focused views and practices also have been criticized in social work literature. Goldstein (1990) points out that a pathology approach tends to reduce the complexities of the human state to narrow compartments of diagnostic schemes. Weick et al. (1989) summarized the problem with problem-focused practice into three points: “(1) the problem invariably is seen as a lack or inability in the person affected; (2) the nature of the problem is defined by the professional; and (3) treatment is directed toward overcoming the deficiency at the heart of the problem” (p. 352). In fact, the prevailing negative perspective was continuously challenged with the new perspectives or models of practice. Attention to capacity-building has been found in the writings of the settlement house workers (Addams, 1910; McMillen et al., 2004), and motivation and opportunities have been mentioned in social casework. In particular, the ecological models and empowerment models have been presented as a challenge to a deficit orientation.

Although social work has taken pride in being a problem-solving profession, problem-focused treatment practice was further criticized and prevention approaches began to be emphasized. According to Goleman (1995), crisis interventions "come too late, after the targeted problem has reached epidemic proportions and taken firm root in the lives of the young" (p. 256). The prevention approach grew out of the realization that it can be more cost-effective and efficient to prevent problems from occurring initially than to treat them after they are established.

Along with criticisms of the problem-focused perspective, positive views on adolescents have increased over last 20 years. Some people who work with young people recognize the power of an alternative approach, one which focuses on the strengths and positive aspects of the youth. This approach views young people as having strengths, assets, potential, or resources, in contrast to the views of youth as problems and victims. Proponents of this approach have recognized that the solutions to many problems that adolescents face can be found in the strengths of young individuals themselves, their families, and their communities (Edwards, Mumford, \& Serra-Roldan, 2007; Maton et al., 2004).

It was in these conditions that the strengths perspective and youth development principles began to attain greater attention among practitioners, researchers, and policy makers working with youth. The strengths perspective has emerged based on the recognition that focusing on the problem does not solve the problem. The strengths perspective is defined as an approach to social work practice that places its emphasis on 
the individual's inner and environmental strengths and resources instead of deficiencies and problems. It was based on the assumption that, despite their adversities, such as mental illness, individuals could build a life beyond the problems. It is rooted in the belief that "people can continue to grow and change and should have equal access to resources" (Chapin, 1995, p. 507). Although the concept of strengths is represented in a variety of forms, Saleebey (2005) suggests a simple device for framing and remembering the essence of the strengths perspective as 3P (promise, possibility, positive expectations), 3C (competence, capacities, courage), and 3R (resilience, reserve, resources).

Although a single definition does not exist, youth development can be defined as "the process in which all youths engage over time in order to meet their needs and their competence” (Nixon, 1997, p. 571). Youth development is explained in three ways: a natural developmental process; a set of principles, a philosophy or approach; and a range of practices in programs, organizations, and initiatives (Hamilton \& Hamilton, 2004). The youth development perspective sees "youth as resources to be developed rather than as problems to be managed” (Roth \& Brooks-Gunn, 2000, p. 3). This perspective assumes that all youth possess individual and ecological assets that have the potential to be marshaled in the service of enhancing their healthy life chances. In contrast to prevention approaches, it moves beyond the eradication of risk and deliberately argues for the positive development and the conditions that contribute to youth health and wellbeing. Youth development advocates assert that simply preventing problems is not enough to prepare youth for adulthood (Borden \& Perkins, 2006).

\section{CONVERGENCE OF A STRENGTHS PERSPECTIVE AND YOUTH DEVELOPMENT: YOUTH PROMOTION}

\section{Development and Application of the Strengths Perspective and Youth Development}

There is a need for a more strengths-focused practice of social work with adolescents. Seita (2000) called for a shift in child welfare practice toward more positive approaches, including incorporating elements of connectedness, continuity, dignity, and opportunity in working with youth. Benard (2004) acknowledges that "the most effective, efficient, and even rewarding and joyful approach to problem prevention is through supporting healthy youth development” (p. 2). Saleebey (2005) also mentioned developmental resilience, health and wellness, and solution-focused approaches as areas of the important "converging lines of research and practice" that support the strengths perspective.

This understanding is supported with the recent growing interest in the development and application of the strengths perspective and youth development to social work practice with adolescents (Barton, 2006; Bender, Thompson, McManus, Lantry, \& Flynn, 2007; Yip, 2006). Needless to say, the strengths perspective is implemented throughout social work practice with youth. This includes adolescents' mental health (Harniss \& Epstein, 2005), substance abuse prevention (Delgado, 1997), child welfare (Collins, 2001), group work (Malekoff, 2004), and juvenile justice (Bazemore \& Terry, 1997), to name but a few. In particular, Rapp (1998) has developed a strengths-based case management model. Poertner and Ronnau (1992) have used a strengths perspective with 
children with emotional disabilities. Laursen (2000) outlines the strengths-based practices that have been found to be effective with challenging children.

A strengths perspective is not limited to social work. It is widely applied in the youth development field. For example, resiliency research offers strong support for the possibility of successful application of strengths perspective to youth development practice. In the words of Benard (2004), "the prevention research community is heartened by the accumulating research evidence that resilience and youth development approaches work" (p. 2). It challenges the youth development field to move beyond a fixation with content to a focus on context. Resilient youth have a set of strengths and competencies that they draw upon.

Recently, youth development practice has been applied to the field of social work with adolescents. According to Melpignano and Collins (2003), "a development relevant to addressing adolescent youth in the child welfare system has been increased attention to principles of positive youth development to help all youth to achieve successful life outcomes” (p. 160). Kim, Crutchfield, Williams, and Helper (1998) describe ways that a youth development approach can be integrated in the prevention of substance abuse and other youth problems. Youth involvement in systems-of-care communities is everevolving (Matarese, McGinnis, \& Mora, 2005).

\section{The Converging Characteristics of the Strengths Perspective and Youth Development}

In addition to these developments of a strengths perspective and youth development practice, some similarities and complementary aspects between these two perspectives emphasize the necessity and importance of a convergence of the two approaches. The first common element of the strengths perspective and youth development is that they both grew from discontent with the problem-focused perspectives, and both transform deficit-based approaches into strengths-based approaches (Rapp, Saleebey, \& Sullivan, 2005). As already discussed, the strengths perspective builds interventions on strengths and de-emphasizes pathology. Positive youth development stresses the values, strengths and potential of children and youth regardless of their situations rather than focusing solely on responses to particular risks.

Second, the strengths perspective and youth development begin with a focus on the positive potential of individuals, families and communities. For the strengths perspective, "almost anything, given circumstances and context can be a strength or asset" (Saleebey, 2005, p. 301). Strengths-based practice facilitates client links to community contexts where client strengths can flourish. Youth development also values internal and external assets, supports and opportunities which denote an ecological perspective. For youth development, one of the goals is that society comes to view youth as community resources rather than community problems (Amodeo \& Collins, 2007).

Third, both perspectives lay stress on the role of helping people and using environmental resources. The strengths practice often involves helping people put together their personal assets and their environmental resources toward the building of a better life. When using the strengths perspective, the relationship is accepting, purposeful, 
and empathetic (Rapp et al., 2005). In addition to the importance of a caring adult, relationships in which youth and adults are partners are considered as the core of youth development (Youngblade \& Theokas, 2006).

\section{Youth Promotion as a Converging Practice of the Strengths Perspective and Youth Development}

When taken together, all the development and application of the strengths perspective and youth development principles serve as a guiding practice toward "youth promotion" as a convergence of the two perspectives. Complementary aspects of the two perspectives are expected to support the strengths of each perspective in synergistic ways.

The importance of a convergence of the strengths-based practices. Convergence is important to supplement the weaknesses of the strengths perspective and positive youth development in the establishment of "youth promotion" practice. There is criticism of the strengths perspective for underplaying the constraints and the often-overwhelming struggles that poor and oppressed people face in their every day lives (Finn \& Jacobson, 2003). Also, youth development is criticized for overlooking the fact that youth face risks that can jeopardize their health and development if not addressed. According to Small and Memmo (2004), "although the likelihood of a problem behavior steadily decreases as the number of assets an individual possesses increases, the presence of even one risk factor can double or triple the occurrence of a problem behavior, even among youth who report many assets” (p. 6).

Efforts of convergence are also significant to embrace youth development principles in the social work field more than ever. Although strong needs and interests in positive youth development programs exist, these have not generally been easily applied in the public child welfare system (Collins, 2001). However, a youth development approach is critical, given that an examination of social work practice literature has suggested that social worker's methodology still predominantly maintains a clinical treatment focus (Morrison et al., 1997).

Convergence contributes to the expansion of the scope and realm of social work with adolescents. The strengths perspective has been applied in case management and thus evolved around the relationship between clients and professional helpers (Arnold, Walsh, Oldham, \& Rapp, 2007). However, youth development is especially popular with group activity situations, such as after-school programs or in the activities of youth-serving organizations (Youngblade \& Theokas, 2006). Therefore, by converging the two perspectives into youth promotion practice, social work within the field of youth expands its practice beyond case management to youth group work as well as beyond welfare agencies to youth-serving organizations.

Definition of youth promotion. As a converging practice, youth promotion can be defined as a process of enhancing youth strengths and resources to promote positive outcomes and help young people be healthy and productive adults. As a synergistic way of convergence, youth promotion can be defined as having complementary goals of the two perspectives. For example, the strengths perspective on youth emphasizes relationship building and youth development focuses on developing the assets of youth 
based on youth-adult relationships (Benson, 2003; 2007; Scales \& Leffert, 1999). Thus, youth promotion practice enhances strengths, relationships, and developmental assets of youth. The promotion of strengths and resources can increase psychosocial and competency-based outcomes and hence reduce risk for problem outcomes. Youth promotion assumes positive acceptance of youth and values their role as active participants in their own positive development. Resources and environments, including adults and professional support, also need to be emphasized in the youth promotion practices. In particular, the mechanisms for identifying and mobilizing youths' strengths need to be developed in the process of implementing services (Morrison et al., 1997).

The term, "promotion" is utilized in the literature of youth development to mean that "efforts [are] specifically designed to bring about clearly defined positive outcomes, or designed to foster the development of skills and competencies in young people" (Halpern, Cusack, Raley, O’Brien, \& Wills, 1995, p. 1). Promotion by this definition accepts the premise that youth have innate strengths and resources that need to be enhanced rather than developed. Promotion also acknowledges use of strengths and promotes young people's strengths (Delgado, 2002).

The term "promotion" is also utilized throughout the social welfare field and other helping professions. As a multidisciplinary concept that is on a continuum ranging from disease prevention to optimal health, the health promotion perspective also stresses capacities rather than deficits. According to Durak (2000), health promotion believes that "individuals have high capacities for growth and development if their physical and social environments provide them sufficient opportunities, guidance, and support” (p. 225). Family promotion is also applied in the family support field with stress on family strengths, informal support and resources, and helping as the mobilization of social and community resources (Dunst, Trivette, \& Deal, 1988).

Practice principles of youth promotion. Practice principles play an influential role in carrying forth the perspectives into the field. The principles of youth promotion, as a social work practice which combines the strengths perspective and youth development, can be inferred from the existing principles of the strengths perspective and other efforts of infusing youth development principles into the social work field. For example, Saleebey (1997) identifies five principles of the strengths perspectives: "(1) every individual, family and community has strengths; (2) trauma, abuse, and struggle may be sources of challenge and opportunity; (3) take individual, group, and community aspirations seriously; (4) collaborating with clients; and (5) every environment is full of resources" (pp. 12-15). Each of these principles serves to guide and direct each element of the strengths approach.

Eccles and Gootman (2002) summarize a list of features of settings that promote youth development based on the best available research: (1) physical and psychological safety; (2) clear and consistent structure and appropriate adult supervision; (3) supportive relationships; (4) opportunities to belong; (5) positive social norms; (6) support for efficacy and mattering; (7) opportunities for skill building; and (8) integration of family, school, and community efforts. 
Delgado's (2000) fourteen strengths principles for effective youth programming in youth development can be applicable to the youth promotion principles. As one of the principles, he recognizes activities for youth to participate in and opportunities for youth to increase their self-esteem. He also suggests a principle of effective youth programs to be built upon what youths value and their assets. According to his principles, programs must (1) emphasize innovative, dynamic, and comprehensive approaches to serving youth, (2) provide youths with opportunities to succeed and contribute to their community, (3) have multiple clear, high, and realistic expectations for participants, (4) be voluntary and provide youth with decision-making powers in shaping programming, (5) be built on quality staff and programming and a willingness to invest resources in support of staff, and (6) emphasize positive intergenerational mentoring relationships.

All of these examples of principles are hypothetical qualities of the strengths-based practices that both meet the needs of developing adolescents and attempt to promote strengths rather than correct deficiencies. These sets of principles can apply to youth promotion practice with minor modifications. In addition, since the strengths perspective builds on the values of the social work profession (Gleason, 2007; Weick et al., 1989), youth promotion practice is also consistent with the Code of Ethics of the National Association of Social Workers, as it acknowledges young people's capacities and strengths, preservation of their dignity, the potential of their circumstances, and promotion of positive aspects of the young person from a value stance of self-worth and respect.

Key principles or themes of youth promotion practice. This promotion-based practice emphasizes two key principles or themes: strengths promotion and relationship promotion. First, strengths promotion is the most critical principle and theme of youth promotion practice. The basis for improving quality of life rests on developing youth strengths, but in order to build strength, one must start with existing strengths. All people can be viewed as having strengths. Existing strengths can be valued, tapped, and enhanced and also new strengths can be acquired and developed. The strengths promotion principle is well inferred from the strengths perspective and youth development principles. For instance, the strengths perspective argues that, to be true to the values of the profession, we need to begin our work by recognizing people's capacities and the potential of their circumstances (Weick, Kreider, \& Chamberlain, 2005). Youth development principles also offer a shift in perspective "away from a focus on correcting 'deficits' in individual youth toward enhancing the potential for healthy youth development in all youth in the community” (Barton, Watkins, \& Jarjoura, 1997, p. 484).

Second, relationships are at the heart of youth promotion practice. Throughout the development of both the strengths perspective and youth development work, the importance of interpersonal relationships in the helping effort has been a constant theme. In the field of youth development, the relationships between young participants and adult youth workers have been shown to be an important protective factor for positive youth development. For the strengths perspective, "clients are engaged as partners; clients least able to function as partners will need an active helper who can structure growth experiences, ensure reasonable goals, and minimize barriers" (Amodeo \& Collins, 2007, 
p. 77). Thus, belief in youth strengths and facilitation of trustful relationship need to be emphasized as basic principles or key themes of the youth promotion practice.

\section{IMPLICATIONS OF YOUTH PROMOTION FOR SOCIAL WORK WITH ADOLESCENTS}

Several advantages emerge as implications of youth promotion for improved social work practice. First, the long-standing dominance of discourse on youth as problems and pathologies can be further challenged and changed. Youth promotion practices are expected to bring into the vision and the vocabulary of social work a compendium of human qualities that are the building blocks of human change. The strengths perspective and youth development approaches clearly focus on human capacity, assets, and aspirations, rather than on deficits and failure (Arnold et al., 2007: Rapp et al., 2005; Saleebey, 2005)

Second, service to targeted youth can be strengthened from the strengths perspective and expanded to the provision of support and opportunities which is advocated by the youth development practice. The strengths perspective offers a way for social workers to move beyond the role of therapy to connect more deeply with the broad roles and goals of the social work profession. As a productive developmental process of growth, youth development can contribute to healthy, satisfying, and productive lives for adolescents by promoting their well-being.

Third, the social work profession can extend its service to the youth development field. One of the challenges that the youth development field faces is the question of who will step forth to claim this practice as their own. Youth development practice needs professionals who can integrate values, skills, knowledge, and leadership into programs (Borden \& Perkins, 2006). However, social work education does not really focus on youth development. Youth promotion practice can supplement the lack of a "home" discipline for youth development, thus allowing social work to expand opportunities for the employment of its graduates.

Despite these advantages, since youth development principles have been incorporated into youth promotion practice, social workers who work with troubled youth tend to experience more challenges than other social workers. For example, social workers in specific agencies have to learn to walk in two worlds. As Chalmers (2000) notes, staff need to learn "how to see youth as competent and as having potential, while also emphasizing problems enough to address important issues and to keep referral sources assured that they are attending to fixing problems and issues” (p. 27). Agencies providing foster care need to become more deliberate in utilizing the strengths perspective and youth development principles to work with youth in care if youth are to reap the benefits of youth development efforts.

Therefore, by converging the two perspectives into youth promotion practice, better professional service, support, and opportunities can be provided to adolescents in need and all young people in the end. If promoted with acceptance and belief in the strengths perspective and positive development, adolescents will produce better outcomes and 
create more confident relationships in the community. Their energy and strengths will contribute to the societal development in a more productive way.

If the social work profession is to be relevant to youth promotion practice, social workers' professed interest in a strengths perspective and youth development is necessary. If social work wants to infuse youth development principles into existing practices, it needs to emphasize "non-traditional” settings, such as youth-serving organizations and community development centers rather than traditional settings of child welfare agencies and schools. Social work education must put more stress on the strengths perspective and positive normal development of youth. As the quest for new conceptual frameworks for practice is essential for continuing innovation and advances in social work, more studies to conceptualize youth promotion are needed for improved social work practice with young people.

\section{References}

Addams, J. (1910). Twenty years at Hull-House. New York, NY: Macmillan.

Amodeo, M., \& Collins, M. E. (2007). Using a positive youth development approach in addressing problem-oriented youth behavior. Families in Society, 88(1), 75-85.

Arnett, J. J. (1999). Adolescent storm and stress, reconsidered. American Psychologist, 54(5), 317-326.

Arnold, E. M., Walsh, A. K., Oldham, M. S., \& Rapp, C. A. (2007). Strengths-based case management: Implementation with high-risk youth. Families in Society, 88(1), 86-94.

Bandura, A. (1964). The stormy decade: Fact or fiction: Psychology in the Schools, 1, 224-231.

Barton, W. H. (2006). Incorporating the strengths perspective into intensive juvenile aftercare. Western Criminology Review, 7(2), 48-61.

Barton, W., Watkins, M., \& Jarjoura, R. (1997). Youths and communities: Toward comprehensive strategies for youth development. Social Work, 42(5), 483-487.

Bazemore, G., \& Terry, W. C. (1997). Developing delinquent youths: A reintegrative model for rehabilitation and a new role for the juvenile justice system. Child Welfare, 76(5), 665-716.

Benard, B. (2004). Resiliency: What we have learned. San Francisco, CA: WestEd.

Bender, K., Thompson, S. J., McManus, H., Lantry, J., \& Flynn, P. M. (2007). Capacity for survival: Exploring strengths of homeless street youth. Child Youth Care Forum, $36,25-42$.

Benson, P. L. (2003). Developmental assets and asset-building communities: Conceptual and empirical foundations. In R. M. Lerner \& P. L. Benson (Eds.), Developmental assets and asset building communities: Implications for research, policy, and practice (pp. 19-43). Norwell, MA: Kluwer Academic Publishers. 
Benson, P. L. (2007). Developmental assets: An overview of theory, research, and practice. In R. K. Silbereisen \& R. M. Lerner (Eds.). Approaches to positive youth development (pp. 33-58). Thousand Oaks, CA: Sage Publications.

Borden, L. M., \& Perkins, D. F. (2006). Community youth development professionals: Providing the necessary supports in the United States. Child \& Youth Care Forum, 35(2), 101-158.

Chalmers, M. (2000). Lessons in strengths-based youth involvement: Minding the mays, the dos and the possibles. Focal Point, 14(2), 24-27.

Chapin, R. K. (1995). Social policy development: The strengths perspective. Social Work, 40(4), 506-514.

Clary, E. G., \& Rhodes, J. E. (Eds.) (2006). Mobilizing adults for positive youth development: Strategies for closing the gap between beliefs and behaviors. New York: Springer.

Collins, M. E. (2001). Transition to adulthood for vulnerable youths: A review of research and implications for policy. Social Service Review, 75(2), 271-291.

Crowe, K. M. (2007). Using youth expertise at all levels: The essential resource for effective child welfare practice. New Directions for Youth Development, 113, 139149.

Day, P. (2000) A new history of social welfare ( $3^{\text {rd }}$ ed.). Boston, MA: Allyn and Bacon.

de Anda, D. (1995). Adolescence overview. In R. L. Edwards (Ed.-in-Chief), Encyclopedia of Social Work (19 ${ }^{\text {th }}$ ed., pp.16-33). Washington, DC: NASW Press.

Delgado, M. (1997). Strengths-based practice with Puerto Rican Adolescents: Lessons from a substance abuse prevention project. Social Work in Education, 19(2), 101-112.

Delgado, M. (2000). New arenas for community social work practice with urban youth: Use of the arts, humanities, and sports. New York, NY: Columbia University Press.

Delgado, M. (2002). New frontiers for youth development in the twenty-first century: Revitalizing and broadening youth development. New York, NY: Columbia University Press.

Dunst, C. J., Trivette, C. M., \& Deal, A. G. (1988). Enabling and empowering families: Principles and guidelines for practice. Cambridge, MA: Brookline Books.

Durak, J. A. (2000). Health promotion as a strategy in primary prevention. In D. Cicchetti, J. Rappaport, I. Sandler, \& R. P. Weissberg (Eds.), The promotion of wellness in children and adolescents (pp. 221-241). Washington, DC: CWLA Press.

Eccles, J., \& Gootman, J. A. (Eds.) (2002). Community programs to promote youth development. Board on Children, Youth, and Families, Division of Behavioral and Social Sciences and Education, National Research Council and Institute of Medicine. Washington, DC: National Academy Press. 
Edwards, O. W., Mumford, V. E., \& Serra-Roldan, R. (2007). A positive youth development model for students considered at-risk. School Psychology International, 28(1), 29-45.

Erikson, E. (1963). Childhood and society ( $2^{\text {nd }}$ ed.). New York, NY: W.W. Norton \& Company.

Finn, J. L. (2001). Text and turbulence: Representing adolescence as pathology in human services. Childhood, 8(2), 167-191.

Finn, L., \& Checkoway, B. (1998). Young people as competent community builders: A challenge to social work. Social Work, 43(4). 335-345.

Finn, L., \& Jacobson, M. (2003). Just practice: Steps toward a new social work paradigm. Journal of Social Work Education, 39(1), 57-78.

Freud, A. (1946). The ego and the mechanisms of defense. New York, NY: International University Press.

Gleason, E. T. (2007) A strengths-based approach to the social development study. Children \& Schools, 29(1), 51-59.

Goldstein, H. (1990). Strengths or pathology: Ethical and rhetorical contrasts in approaches to practice. Families in Society, 71(5), 267-276.

Goleman, D (1995). Emotional intelligence. New York, NY: Bantam Books.

Hall, G. S. (1904). Adolescence: Its psychology and its relations to physiology, anthropology, sociology, sex, crime, religion, and education. New York, NY: D. Appleton \& Company.

Halpern, S. J., Cusack, G., Raley, R., O’Brien, R., \& Wills, J. (1995). Contract with America's Youth: Toward a national youth development agenda. Washington, DC: American Youth Policy Forum.

Hamilton, S. F., \& Hamilton, M. A. (2004). The youth development handbook: Coming of age in American communities. Thousand Oaks, CA: Sage Publications.

Harniss, M. K., \& Epstein, M. H. (2005). Strength-based assessment in children's mental health. In M. H. Epstein, K. Kutash, \& A. J. Duchnowski (Eds.), Outcomes for children and youth with emotional and behavioral disorders and their families: Programs and evaluation best practices ( $2^{\text {nd }}$ ed., pp.125-141). Austin, TX: Pro-ed.

Kim, S., Crutchfield, C., Williams, C., \& Helper, N. (1998). Toward a new paradigm in substance abuse and other problem behavior prevention for youth: Youth development and empowerment approach. Journal of Drug Education, 28(1), 1-17.

Laursen, E. K. (2000). Strength-based practice with children in trouble. Reclaiming Children and Youth, 9(2), 70-75.

Malekoff, A. (2004). Strengths-based group work with children and adolescents. In C. D. Garvin, L. M. Gutierrez, \& M. J.Galinsky (Eds.). Handbook of social work with groups (pp. 245-258). New York, NY: The Guilford Press. 
Males, M. (1996). The scapegoat generation: America's War on Adolescents. Monroe, ME: Common Courage.

Matarese, M., McGinnis, L., Mora, M. (2005). Youth involvement in systems of care: A guide to empowerment. Washington, DC: Technical Assistance Partnership.

Maton, K. I., Schellenbach, C. J., Leadbeater, B. J., \& Solarz, A. L. (2004). Investing in children, youth, families, and communities: Strengths-based research and policy. Washington, DC: American Psychological Association.

McMillen, J. C., Morris, L., \& Sherraden, M. (2004). Ending social work’s grudge match: Problems versus strengths. Families in Society, 85, 317-325.

Mead, M. (1928). Coming of age in Samoa. New York, NY: Dell.

Melpignano, M., \& Collins, M. E. (2003). Infusing youth development principles in child welfare practice: Use of a Delphi survey to inform training. Child and Youth Care Forum, 32(3), 159-173.

Morrison, J. D., Alcorn, S., \& Nelums, M. (1997). Empowering community-based programs for youth development: Is social work education interested? Journal of Social Work Education, 33, 321-333.

Nichols, S. L., \& Good, T. L. (2004). America's teenagers-myths and realities: Media images, schooling, and the social costs of careless indifference. Manwah, NJ: Lawrence Erlbaum Associates.

Nixon, R. (1997). What is positive youth development? Child Welfare, 76(5), 571-575.

Poertner, J., \& Ronnau, J. (1992). A strengths approach to children with emotional disabilities. In D. Saleebey (Ed.), The strengths perspective in social work practice (pp. 111-121). New York, NY: Longman.

Rapp, C. A. (1998). The strengths model: Case management with people suffering from severe and persistent mental illness. New York, NY: Oxford University Press.

Rapp, C. R., Saleebey, D., \& Sullivan, W. P. (2005). The future of strengths-based social work. Advances in Social Work, 6(1), 79-90.

Roth, J., \& Brooks-Gunn, J. (2000). What do adolescents need for healthy development? Implications for youth policy. Social Policy Report, 14(1), 3-19.

Saleebey, D. (Ed.). (1997). The strengths perspective in social work practice ( $2^{\text {nd }}$ ed.). New York, NY: Longman.

Saleebey, D. (Ed.). (2005). The strengths perspective in social work practice ( $4^{\text {th }} \mathrm{ed}$.). Boston, MA: Pearson Education, Inc.

Scales, P. C. (2001). The public image of adolescents. Society, 38(4), 64-70.

Scales, P. C., \& Leffert, N. (1999). Developmental assets: A synthesis of the scientific research on adolescent development. Minneapolis, MN: Search Institute. 
Seita, J. R. (2000). In our best interest: Three necessary shifts for child welfare workers and children. Child Welfare, 79(1), 77-92.

Small, S., \& Memmo, M. (2004). Contemporary models of youth development and problem prevention: Toward an integration of terms, concepts, and models. Family Relations, 53(1), 3-11.

Trattner, W. I. (1999). From poor law to welfare state: A history of social welfare in America ( $6^{\text {th }}$ ed.). New York, NY: The Free Press.

Weick, A., Kreider, J., \& Chamberlain, R. (2005). Solving problems from a strengths perspective. In D. Saleebey (Ed.), The strengths perspective in social work practice ( $4^{\text {th }}$ ed., pp. 116-127). Boston, MA: Pearson Education, Inc.

Weick, A., Rapp, C., Sullivan, W. P., \& Kisthardt, W. (1989). A strengths perspective for social work practice. Social Work, 34, 350-354.

Yip, K. (2006). A strengths perspective in working with an adolescent with self-cutting behaviors. Child and Adolescent Social Work Journal, 23(2), 134-146.

Youngblade, L. M., Theokas, C. (2006). The multiple contexts of youth development: Implications for theory, research, and practice. Applied Developmental Science, 10(2), 58-60.

\section{Author's note:}

Address correspondence to: Jeong Woong Cheon, Ph.D., School of Social Welfare, University of Kansas, 1545 Lilac Lane, Lawrence, KS 66044-3184. Email:

jwcheon@ku.edu. 